\title{
Blogs: problema da literatura enquanto arte à luz da teoria estética de Adorno
}

Bruno Lima Oliveira, Endereço: Universidade do Estado do Rio de Janeiro, Programa de Pós-graduação Stricto Sensu em Letras; Email: <brunolima74@gmail.com>.

\begin{abstract}
Resumo:
É comum os estudos críticos sobre literatura contemporânea referirem-se ao retorno do autor. Sua participação midiática, em feiras literárias, congressos, palestras e lançamentos de livros, além da crescente hibridização de autobiografia e ficção, ainda suscitam teses interessadas em discutir o que propicia a chamada autoficção e em questionar até que ponto seria válido falar em um novo "realismo", a partir das considerações de Hal Foster. Este trabalho pretende caminhar na contramão do que vem sendo estudado atualmente pela Academia, no sentido de que não visa compreender a produção literária deste século extraliterariamente, ou seja, as respostas que se quer alcançar para explicar a autoficção não se encontram apenas em nossa sociedade do espetáculo, mas, sobretudo, no próprio texto e, mais particularmente, em uma outra mídia - os blogs. Será a partir da análise do labor literário na internet que se conseguirá problematizar, à luz da teoria estética de Theodor Adorno, a própria literatura enquanto arte. Um novo conceito de narrador, de autor e da própria literatura são possíveis de se teorizar ao comparar a produção literária contemporânea praticada na internet com aquela publicada e editada em outro veículo midiático, seja em livros do século passado como deste século XXI.
\end{abstract}

Palavras-chave: autoficção, autor, narrador, blog, literatura, arte.

O autor não mais está morto. As leituras formalista e estruturalista, apesar de ainda possíveis de serem feitas, cederam espaço para uma nova compreensão literária, em que a figura autoral assume posição de relevo. Hoje, presente extra e literariamente, fica muito difícil ignorar o sujeito empírico autoral no universo ficcional. Nossa sociedade de massas, midiática e imagética, propicia que o escritor seja visto e reconhecido em feiras literárias, congressos, palestras, lançamentos de livro e programas de televisão. Desse modo, é comum que o leitor muitas vezes conheça o autor sem dele nunca ter lido obra alguma, como já anotou Lejeune, afinal, 
inserido na Indústria Cultural, o autor tornou-se uma celebridade, de acordo com Italo Moriconi.

Além da visibilidade midiática, o texto literário também hibridiza empiria e fabulação, autobiografia e ficção. Por um lado, apolineamente, o reconhecimento do autor na obra ficcional salta aos olhos, mas, por outro, a incerteza sobre a veracidade dos fatos narrados aproximam o leitor do caos de Dioniso. É a chamada autoficção, que pode ser entendida, dentre outras teorizações, como uma crítica ao exibicionismo e ao voyeurismo comuns em nosso tempo, em que webcams, redes sociais, reality shows e blogs performatizam e lançam luz sobre um eu que se situa no interstício entre realidade e ficção.

Nesse sentido, interessa-me observar como a literatura responde ao novo suporte que the serve como veiculação: os blogs. Os diários virtuais na internet diferem dos diários manuscritos em agendas e cadernos porque estes eram escritos, via de regra, secretamente, longe de olhares indiscretos e curiosos de quaisquer leitores; os blogs, objeto deste estudo, ao contrário, são publicados na internet, para leitores conhecidos e desconhecidos. A pudicícia, a discrição e o recato presentes nos diários são substituídos pela exibição, performance e invenção de si que constituem os blogs.

O tempo é outra peculiaridade importante na comparação entre os diários materiais e virtuais. Normalmente, a leitura de um diário se dava post-mortem, isto é, sempre a posteriori do tempo da narrativa. Diários de escritores consagrados, após seu falecimento, acabam por contribuir com novas informações tanto acerca do sujeito que ali se inscreveu quanto lançando luz sobre sua obra literária, já publicada, lida e estudada. Temos, portanto, uma leitura retrospectiva capaz de reatualizar o tempo presente. Com os blogs não é isso o que ocorre. Nas palavras da escritora e blogueira Cecília Giannetti, "os blogs não têm pósteros, têm contemporâneos" (apud Viegas, 2008:142), isto é, trata-se de uma escrita de si autoficcional que visa a apreender o tempo presente no próprio presente. É 
como se o sujeito contemporâneo não soubesse mais de onde veio - pois perdera a tradição, lembremo-nos de Benjamin - e, por outro lado, ignorasse para onde vai. Restar-lhe-ia apenas o "aqui agora", que necessita ser preservado.

É curiosa essa fixação pelo tempo presente da atualidade porque, seguindo a teorização estética de Adorno, o homem ou está olhando para o futuro ou relembrando o passado, jamais no presente. Ainda segundo Adorno, apenas a arte está no presente. Nesse sentido, vale uma reflexão mais sistemática sobre a literatura praticada em blogs - que muitas vezes migra para o livro, confundindo os suportes.

Escrita datada e serial, ela se dá cotidianamente e ficcionaliza o próprio cotidiano, em que a vida ordinária e comum recebe tratamento literário. $\mathrm{O}$ narrador em primeira pessoa, ao rememorar fatos banais e desimportantes do dia a dia e publicá-los nos blogs, está, em primeiro lugar, imiscuindo-se às vivências autorais e baralhando empiria e ficção, de modo a se tornarem indecidíveis seus limites. Assim, um nova conceituação de realidade, ficção, literatura e sujeito se torna pertinente e necessária, ao menos para problematizá-la. É possível argumentar que a autoficção desestabiliza tais conceitos, outrora estanques. Existiria realidade? Tudo não passaria de ficção, no sentido de que o real se constrói via linguagem, como defende, dentre outros, Gustavo Bernardo? Quem é o sujeito que se hibridiza e performatiza no texto ficcional, mas com um pé na empiria? O que é, afinal, literatura hoje? Há resposta para esta última pergunta?

Um contra-argumento para as questões elencadas acima poderia defender que a "novidade" que os blogs apresentam já estavam presentes no labor literário desde sempre. Um exemplo de um texto datado, serial, escrito em primeira pessoa e que, em certo sentido, confundiria autor e narrador é Memorial de Aires, de Machado de Assis. Lúcia Miguel Pereira, por exemplo, em estudo crítico-biográfico, aponta no Conselheiro o alterego de Machado. Para a ensaísta, criador e 
criatura se confundem a tal ponto que, "em 1892, quem escreve os folhetins da Semana, sob o pseudônimo de Machado de Assis, é o velho Aires" (Pereira, 1955: 244-5). A diferença, essencial, a meu ver, é que o romance do bruxo foi lido como um todo acabado, ao passo que os blogs são escritos, publicados e lidos numa espécie de work in progress, em que os tempos da publicação e da leitura são, em alguns casos, sincrônicos. Outra diferença reside justamente no suporte. A publicação em papel inviabilizava a modificação textual, ao passo que os blogs permitem ao autor alterar quantas vezes julgar necessário seu texto, inclusive a partir do dialogismo com o leitor, que pode sugerir modificações possivelmente acatadas pelo blogueiro. Desse modo, o tempo presente em que se situa as escritas de si do blog estariam sendo revisitadas a posteriori, atualizando o próprio presente.

O registro ficcional da banalidade ordinária do narradorblogueiro, em segundo lugar, traz à baila outro ponto importante a ser investigado na literatura do século XXI: a estética do comum. $O$ autor contemporâneo não é mais considerado o gênio de outrora; é uma pessoa vista e reconhecida nos vários media em que circula. Em muitos casos, sua persona pública é mais conhecida do que sua própria obra, como dito anteriormente. Além disso, na internet abundam blogs de diletantes amadores, que narram igualmente suas idiossincrasias e vivências corriqueiras, cujas leituras são plurais a julgar pelo número de seguidores do blog. O que motivaria o interesse pela ficcionalização de um sujeito desconhecido, uma vez que não integra o circuito literário e não tem acesso à grande mídia? A popularização de reality shows e das redes sociais indica que é crescente a atenção dispensada a pessoas comuns, de modo a indicar que a realidade, cada vez mais transfigurada em ficção, assume status de importância. $O$ homem comum almeja atingir a posição de celebridade, do mesmo modo que esta é, paradoxalmente, constituída por homens comuns, formando, 
assim, nossa sociedade do espetáculo, como bem a delineou Guy Debord.

Leonor Arfuch, Denilson Lopes e Silviano Santiago são estudiosos que têm se dedicado a avaliar esse recíproco interesse. Nas palavras de Silviano,

agora, o homem comum começa a chegar à posição de artista. Nunca o homem esteve tão perto de sua plenitude: ele não tem mais desculpas metafísicas. Não tem mais nada sobre o que possa projetar-se. Está livre da irresponsabilidade. Não pode mais nem mesmo negar-se como ser total. Já que nenhuma transferência é mais possível, resta-lhe viver o presente, a arte sem arte, como uma nova realidade (Santiago, 2011: 27-8).

Silviano conclui seu raciocínio afirmando que, inversa e paradoxalmente, o artista também encaminha-se para a posição de homem comum. As narrativas banais, corriqueiras, desimportantes e empíricas de autores-narradores comuns e desconhecidos encontram nos blogs um excelente suporte para tal prática literária. Esta parece ser a gênese de uma nova maneira de se pensar a literatura, a arte, a partir de uma veiculação propícia a tal demanda.

O fato dos blogs dispensarem a intermediação de um editor e do texto não necessitar da submissão à aprovação por um grupo de "especialistas" torna-o um veículo bastante democrático, no qual escrevem escritores devidamente editados, consagrados e premiados, além de diletantes amadores que ou querem ascender literariamente ou escrevem na internet por prazer e porque é uma maneira fácil e rápida de se dizer o que the convier. A esse respeito, inclusive, é interessante observar que, num país em que a leitura é pouco apoiada e incentivada, cresce o número de pessoas que se dispõem a narrar-se a si próprios, ficcionalizando-se. Erigem-se novos escritores no cenário literário e, em igual medida, o texto abandona a horizontalidade da edição impressa em livro e verticaliza-se na tela do computador. Talvez possa ser esta uma correlação entre a necessidade e vontade de escrever e ser lido com o formato em que é veiculado o texto $2.0-$ a 
literatura ergue-se e fica de pé, semelhante a uma obra plástica que abandona a tela e corporifica-se enquanto escultura. Diante da dificuldade mercadológica de entrar no cenário das grande editoras, tanto autor quanto texto põem-se de pé, tornando-se visíveis.

O que é visto/lido é uma obra que transcende o literário, ou melhor, reconfigura-o. A literatura, agora, não é apenas textual, mas também visual, imagética, poliforme, audível, intertextual, enfim, multimidiática. O veículo em que ela se insere suporta uma gama ampla de mídias, inaugurando novas possibilidades de se pensar a literatura para além do cânone vigente. Diferentemente do livro, os blogs possibilitam um diálogo aberto entre blogueiro e leitores, ou mesmo entre diferentes blogueiros, no sentido de que é comum haver links que ligam um blog a outro, numa espécie de filiação identitária ou temática. Luiza Lobo, a respeito do processo de comunicação estabelecido pelo blog, afirma que

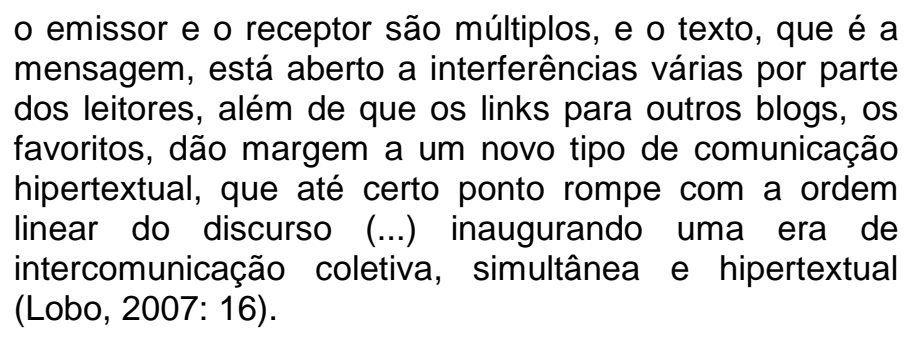

O dialogismo possível com os blogs coloca em suspenso, por exemplo, a noção de autoria, pois se um autor escreve um texto e, nos comentários, um leitor o critica e sugere uma alteração, caso acatada a mudança, de quem é a autoria do texto, de quem o escreveu inicialmente, de quem sugeriu a modificação ou de ambos? O mesmo processo de leitura crítica certamente também ocorreu com Machado, citado anteriormente, mas no caso das edições impressas, sejam quais forem, tal diálogo se perde, posto que só temos acesso à edição final. Nos blogs, é visível e concomitante todo esse processo, haja vista que é público e irrestrito. 
Mais do que avaliar a verticalização textual, interessa-me salientar uma outra característica, a meu ver, inovadora dessa prática literária: a invenção de si. Pode-se objetar que toda e qualquer narrativa é ficcional no sentido de que é impossível a narração da realidade, como aferiu Costa Lima. Assim, a autobiografia não corresponderia a uma verdade factual, mas traria laços estreitos com a ficção. Sobre esse ponto de vista, a autoficção da prosa contemporânea deixaria de ser relevante, pois seria considerada meramente ficcional e a discussão a respeito da interseção entre realidade e ficção perderia o sentido. Contudo, a despeito de questões teóricas sobre a impossibilidade de se narrar a realidade, é inegável que a literatura praticada sobretudo nos blogs flerte apaixonadamente com o real, aqui entendido como algo que de fato aconteceu, sem maiores preocupações filosóficas. As narrativas em primeira pessoa de indivíduos comuns estão alicerçadas na vivência empírica de seus autores-narradores, com maiores ou menores doses de ficcionalização. Clarah Averbuck, sobre seu romance de estreia Máquina de pinball, que é uma bricolagem de textos escritos no blog e outros produzidos com a finalidade editorial, a respeito da protagonista da obra, Camila, ser seu alterego, afirma:

Sou eu. Não tem o que se infiltrar. Sou eu e é uma ficção. A partir do momento que está escrito, não interessa se é verdade ou não. As pessoas se preocupam muito com isso. Aconteceu ou não? As pessoas sabem o que eu deixo elas saberem. Eu só quero escrever e não me incomodem muito. Elas deviam ler e não se importar tanto (Averbuck, 2007).

Averbuck é taxativa na sua resposta. Sim, a Camila é ela, autora; e sim, o romance é ficção. O que ela parece querer dizer é que se utilizou como arquétipo para a criação de sua personagem, mas que isso não faz de sua literatura um texto apenas referencial. Ele é, de acordo com Clarah, ficção, ou, se preferirmos, autoficção; afinal, mesmo que não se consiga distinguir realidade e ficção no romance, Camila é a persona de Clarah Averbuck. 
Minha hipótese de trabalho, nessa direção, é a de que o autor contemporâneo, limitado ao que se convencionou chamar literatura, dá um passo importante para a sua reinvenção mediante as tecnologias que possibilitam essa nova estética. Ao utilizar-se como matéria-prima para sua ficção, autoficcionalizando-se, o escritor, na realidade, abandona 0 fazer literário, já gasto e, aparentemente, incapaz de assumir outras vanguardas. A recorrência a um narrador em primeira pessoa se daria, em primeiro lugar, como alternativa encontrada à crise da narração apontada por Benjamin. Se não há mais intercâmbio de experiências, restaria ao eu que escreve narrar a si próprio. O artista, nesse cenário, entretanto, diante do impasse da arte moderna que resultaria em sua morte, de acordo com Adorno, dá um passo além e decisivo não escreve mais literatura, abandona-a para, em seguida, elevá-la e elevar-se a um novo patamar. O que o autor propõe, com a autoficção nos blogs, é fazer de si próprio literatura, a performatizar um eu e tornar-se obra de arte. A ficcionalização de si, nesse sentido, viria para dar uma outra direção à literatura, ou seja, quando o escritor contemporâneo utiliza-se como matéria-prima para a sua obra, ele não estaria criando uma obra literária, mas sim, indo ao extremo, fazendo de si próprio literatura. Ficcionalizar sua vida empírica, utilizar-se como personagem ficcional, pode ser uma tentativa de se eternizar em um outro tempo, não mais cronológico, mas artístico. Mais do que isso, a invenção de si nos blogs seria um modo de transcender a escrita literária, cujo resultado não seria mais o texto, mas sim um novo conceito de produção artística calcado na figura empírica de quem faz de si uma performance textual, portanto, ficcional; em suma, a literatura conformaria uma nova conceituação e teorização.

\section{Referências}

Adorno, T. Teoria estética. (2008). Lisboa: Edições 70.

Arfuch, L. (2010). O espaço biográfico: dilemas da subjetividade contemporânea. Rio de Janeiro: EdUERJ. 
Assis, M. (s/d). Memorial de Aires. s/l. Klick editora.

Averbuck, C. (2007). Personagem de si mesma. Disponível em: http://wwwb.click21.mypage.com.br/MyBlog/visualiza_blog.asp?site=c lickinversos.myblog.com.br\&primpost=m52Tk87Jje4go30em8IT71041 72728IRYHH3HOPF\&inframe=T. . (2002). Máquina de pinball. São Paulo: Conrad Editora do Brasil.

Benjamin, W. (1994). Magia e técnica, arte e política: ensaios sobre literatura e história da cultura. São Paulo: Brasiliense.

Debord, G. (s/d). A sociedade do espetáculo. Rio de Janeiro: Contraponto.

Krause, G.B. (2010). O livro da metaficção. Rio de Janeiro: Tinta Negra Bazar Editorial.

Lejeune, P. (2008).O pacto autobiográfico: de Rousseau à internet. Belo Horizonte: Ed. UFMG.

Lima, L.C. (1986). Júbilos e misérias do pequeno eu. In:

Sociedade e discurso ficcional. Rio de Janeiro: Guanabara.

Lobo, L. (2007). Segredos públicos: os blogs de mulheres no Brasil. Rio de Janeiro: Rocco.

Lopes, D. (2012). No coração do mundo. Rio de Janeiro: Rocco.

Moriconi, I. (2006). Circuitos contemporâneos do literário: indicações de pesquisa. Gragoatá, Niterói, n. 20, p. 147-163.

Nietzsche, F. (1992). O nascimento da tragédia ou helenismo e pessimismo. São Paulo: Cia. das Letras.

Oliveira, B.L. (2010). A autoficção no campo da escrita de si: a construção do mito do escritor em Nove noites, de Bernardo Carvalho, e outros procedimentos autoficcionais na prosa de ficção contemporânea. Dissertação (mestrado). Universidade do Estado do Rio de Janeiro.

Pereira, L.M. (1955). O Conselheiro Aires In: Machado de Assis: estudo crítico e biográfico. Rio de Janeiro: José Olympio.

Santiago, S. (2011). "Sentimento da vida, sentimento do mundo". Princeton (Mimeo).

Viegas, A.C. (2008). Experiência e espetáculo na escrita de si contemporânea. In: Chiara, A.; Rocha, F.C.D. (orgs.). Literatura 
brasileira em foco: o eu e suas figurações. Rio de Janeiro: Casa Doze. 